\title{
Eucalypts and Their Potential for Invasiveness Particularly in Frost-Prone Regions
}

\author{
Trevor H. Booth \\ CSIRO Ecosystem Sciences and CSIRO Climate Adaptation Flagship, GPO Box 1700, Canberra, ACT 2601, Australia
}

Correspondence should be addressed to Trevor H. Booth, trevor.booth@csiro.au

Received 20 March 2012; Accepted 10 May 2012

Academic Editor: Matias Kirst

Copyright () 2012 Trevor H. Booth. This is an open access article distributed under the Creative Commons Attribution License, which permits unrestricted use, distribution, and reproduction in any medium, provided the original work is properly cited.

Eucalypts are being considered for biofuel production in the Lower Coastal Plain of the United States. The evolution of eucalypts in Australia has equipped some species to be successful in plantations and has also influenced their potential as invasive species. More than 200 eucalypt species have been evaluated in many countries around the world. Generally eucalypts have proved to have limited invasive potential for a number of reasons, including their poor dispersal capabilities. Two regions with climates similar to the Lower Coastal Plain of the United States are identified in Argentina and China. Frosts, particularly sudden frosts, are an important limitation for eucalypts in these regions, so existing plantations are very limited. However, invasive eucalypts do not appear to be a major problem in other regions of either country. The use of carefully selected frost-tolerant species and the development of genetically modified eucalypts may now open up more frost-affected areas for eucalypt plantations. Some control actions may be necessary and research needs are outlined, but it is concluded that experience in other regions around the world suggests that eucalypts are likely to be a relatively low risk as invasive species in the Lower Coastal Plain.

\section{Introduction}

There is increasing interest in establishing short rotation eucalypt plantations in the Lower Coastal Plain of the United States to meet biofuel needs. Gonzalez et al. [1] identified Eucalyptus camaldulensis, E. benthamii, E. viminalis, E. macarthurii, E. grandis, E. robusta, E. saligna, and the hybrid "E. urograndis" (E. urophylla $x$ E. grandis) as taxa that have shown promise for the region in past trials. Current field trials are providing more information on suitable species [2], but before committing to major developments there is a need to consider potential environmental issues.

Loehle et al. [3] have reviewed the potential invasiveness of the nine prospective species identified by Gonzalez et al. [1], while this paper takes a somewhat different but complementary approach. First, the evolution of eucalypts in Australia is considered briefly to help understand the factors that have made the genus successful in plantations in many countries, as well as influencing the degree to which they may, or may not, be a major problem as invasive species. Second, the general experience with introduction of eucalypts around the world and the extent to which they have proved invasive is described. Third, locations around the world with similar climatic conditions to the Lower Coastal Plain are identified and experiences with eucalypt plantations and invasiveness problems in these particular regions are described. Finally, the discussion and conclusion sections assess the general level of risk of eucalypts becoming invasive in the Lower Coastal Plain, control actions that may be necessary, and research needs to reduce risk.

Before considering eucalypts and invasiveness, it is worth considering the difference between weeds and invasive species. As defined by Simberloff and Rejmánek [4] a weed is "an unwanted plant, usually perceived as detrimental to human interests." They provide two definitions for invasive species. The first usually used by ecologists is "a naturalized species that produces reproductive offspring, often in large numbers and that spreads over large areas." The second definition, equivalent to "non-native pest species" often used by managers particularly in the United States, is "a nonindigenous species that spreads rapidly, causing environmental or economic damage." In some cases eucalypts may be considered to be unwanted plants, but this paper focuses on 
how strong or weak are their capabilities to escape from existing plantation areas and invade adjacent areas.

\section{Eucalypts and Their Characteristics}

The story of eucalypts in Australia begins some 45 million years ago with the appearance of fossil evidence from rocks near Lake Eyre [5]. At about this time the Australian landmass was drifting north with the climate becoming drier, fires being more frequent, and the soil conditions becoming poorer. It took more than 35 million years for eucalypt pollen to move from being merely present in the fossil pollen record to being abundant [6]. However, in the long term eucalypts proved to be remarkably successful in adapting to the changing conditions across the Australian continent, with a few species also extending to parts of Indonesia, Papua New Guinea, and the Philippines, and two species only being found in regions outside of Australia.

The group of species commonly known as "eucalypts" includes more than 700 species in the genera Eucalyptus and Corymbia, with another ten or so species in the closely related Angophora genus. The exact number of species is somewhat fluid, as taxonomists debate whether particular distinctive forms should be recognised as separate species. There is even debate about whether about 110 species should be included in the genus Eucalyptus, as they were in the Flora of Australia [7], or in the separate genus Corymbia. For the purposes of this paper, species in the genus Corymbia are included as eucalypts.

What are some of the key characteristics of Australia to which eucalypts have had to adapt? Australia is the sixth largest country in the world and has an area of $7,682,300 \mathrm{~km}^{2}$, not far short of the $8,080,464 \mathrm{~km}^{2}$ of the contiguous United States. Climatic conditions across the vast Australian continent range from temperate to tropical. Low precipitation levels are characteristic of most of the continent with about 80 percent of the landmass receiving less than $650 \mathrm{~mm}$, about 50 percent less than $350 \mathrm{~mm}$ and over 33 percent less than $250 \mathrm{~mm}$ per annum. However, these mean values are somewhat misleading as Australia has unusually variable rainfall. For example, many locations in the State of Victoria in southeastern Australia received less than average rainfall for twelve consecutive years in the 1997-2008 drought. Conversely, long dry periods are often followed by flooding rains, such as those in western and central parts of the State of Victoria between 12-14 January 2011, with Jeparit (average annual rainfall $362 \mathrm{~mm}$ ) receiving $161 \mathrm{~mm}$ in one day.

Fire occurs regularly over the northern part of the continent as a result of lightning strikes, and fire was also widely used as part of land management by the Aboriginal population, that arrived more than 50,000 years ago. In present times, long dry periods followed by high temperatures and strong winds still create conditions very favorable for bushfires [8]. Climate is one of the important factors, which along with organisms, relief, parent material, and time affects soil formation. In relation to most Northern Hemisphere soils, Australian soils are generally old in origin and poor in quality, being low in nutrients particularly phosphorus with very limited organic matter often overlying impermeable clay close to the surface [9].

What are the characteristics that have helped eucalypts become so ubiquitous across Australia? The ecology of eucalypts, including their evolutionary biogeography, has been described in detail by Williams and Woinarski [10]. In comparison to some groups, such as casuarinas, which millions of years ago used to be more prominent in the Australian flora, eucalypts are well adapted to withstand and/or reestablish after bushfires (wildfires). One adaptation particularly relevant to their fire resistance, as well as their relatively weak invasive potential, is that seed are held on the tree in protective capsules. Some seed is released as it matures, but some fruits are late in opening, and will open following fire, which can result in massive seed falls after bushfires. The capsules, which provide some protection from fires, are not generally attractive to animal vectors. The seed also tend to be very small and usually lack any aerodynamic aids that could assist wind dispersal. So, the area of seed dispersal is related to tree height, crown diameter, wind velocity, mass, and terminal velocity of seed and has been estimated at about $39 \mathrm{~m}$ for $30 \mathrm{~m}$ tall E. marginata trees $[11,12]$. Once the seeds are released from the capsule and on the ground, they are readily eaten by insects, and in one study half the seeds were eaten within five days [13]. The small seeds require bare soil to germinate and cannot establish in a grass sward or on organic mulch layers. They are light demanding and will not grow successfully under closed forest or understory canopies, and only remain viable in soil for less than a year [14]. Records of invasiveness of nonlocal eucalypts in Australia suggest spread rates of only about one meter per year [15].

An additional point that follows from the short life of eucalypt seeds is that it is relatively easy to eradicate eucalypts as weeds. As sexual maturity is usually only after several years and the soil seed store is short lived, removal of mature trees followed up by removal of any seedling germinants before sexual maturity is reached (i.e., within the next few years) results in eradication. This is not the case with acacias where seeds will keep germinating for many years.

In addition to their adaptations to fire, of which seed capsules are just one, eucalypts have adapted to grow on poor soils under very variable climatic conditions. Eucalypts have no dormant growth period and remain ready to grow when favorable conditions occur. Being evergreen allows eucalypts to take advantage of highly variable climatic conditions. The leaves of many exotic species wilt under the extremely hot and dry conditions that are experienced in Australia. In contrast the sclerophyllous leaves (i.e., hard leaves with well-developed sclerenchymatous tissue) of eucalypts allow them to withstand very dry conditions [16] and may also be an adaptation to low nutrient conditions [17]. The ability to grow whenever conditions are favorable is an important factor in the success of eucalypts as plantation species.

\section{Global Eucalypt Plantations and Invasiveness}

Two books, a map, and a recent scientific paper together provide a good introduction to the success of eucalypts as 
plantation species outside Australia. The book Eucalypts for Planting [18] summarises results of eucalypt introductions into 92 countries as well as describing the characteristics of 110 species. Species elimination trials were a major part of these early introductions. Provenances (i.e., unimproved seed collected from specific locations in the wild) of particular species were evaluated. Eucalypts proved to be particularly successful in tropical and subtropical regions. They were also successful in some temperate regions, but problems with sudden and severe frosts were a limitation in regions such as northern Florida, Georgia (in the then USSR), and parts of China. Such information is relevant to invasiveness, as a prerequisite for invasiveness is that a species has to be capable of growing in a particular region.

As successful species and provenances were identified from species elimination trials the focus turned to tree improvement of a much reduced group of species. Eldridge et al. [19] described how tree productivity could be improved by careful selection and breeding of first and second generations following collections from native stands. Current plantations around the world are dominated by the "big nine" species identified in a paper by Harwood [20] as E. camaldulensis, E. grandis, E. tereticornis, E. globulus, E. nitens, E. urophylla, E. saligna, E. dunnii, and E. pellita and their hybrids, which together account for more than $90 \%$ of the major eucalypt plantations. Much of current tree improvement efforts focus on the use of hybrids and clones, and development of genetically modified eucalypts is already underway [21]. A USDA/APHIS Environmental Assessment [22] relating to an ArborGen LLC proposal to establish 28 trial sites within the Lower Coastal Plain for "field testing of genetically engineered Eucalyptus grandis $x$ Eucalyptus urophylla" considered invasive potential in some detail and found "no significant impact" was likely.

Total eucalypt plantations around the world are now more than 20 million hectares, and a map produced by GIT Consulting [23] illustrates the countries where these plantations are located. Major centers include Brazil ( $4.2 \mathrm{~m} \mathrm{ha})$, India (3.9 m ha), and China (2.6 m ha).

Considering that so many eucalypt species have been grown so widely around the world invasiveness problems have been generally limited. Haysom and Murphy [24] and Richardson and Rejmánek [25] have reviewed the invasiveness of forest tree species around the world. Haysom and Murphy [24] noted Eucalyptus globulus as an invasive species in California and Hawaii. No eucalypts were listed as invasives in Europe. Eucalypt species considered invasive in southern Africa included Corymbia citriodora, E. camaldulensis, E. cladocalyx, E. diversicolor, E. globulus, E. grandis, E. lehmannii, E. microcorys, E. paniculata, E. robusta, E. sideroxylon, and E. tereticornis. For New Zealand, E. botryoides, E. globulus, and E. saligna were listed as invasive. E. camaldulensis and E. robusta were listed as invasives in South America. Richardson and Rejmánek [25] considered only eight eucalypt species to be invasive including Corymbia maculata, E. camaldulensis, E. cinerea, E. cladocalyx, E. conferruminata, E. globulus, E. grandis, and E. robusta. Southern Africa was a particular problem area with Corymbia maculata, E. camaldulensis, E. cinerea, E. cladocalyx, E. conferruminata, and E. grandis being considered invasive. E. conferruminata is sometimes mistaken for E. lehmannii, but the naturalized and sometimes invasive species is E. conferruminata. In contrast to Haysom and Murphy, they identified invasive eucalypts in Europe, considering E. camaldulensis invasive in Spain and E. globulus in Portugal. However, they commented that as eucalypts have been "exceptionally well disseminated and widely planted for well over a century in many parts of the world. . .surprisingly few species are listed as invasive...".

Why do eucalypts appear to be more of a problem in southern Africa than elsewhere? In comparison to some other major eucalypt growing areas such as Brazil and China, eucalypts were introduced into southern Africa relatively early, initially about 1828 . They were widely planted in South Africa from about 1850, more than 50 years before the introduction of eucalypts into Brazil, and their establishment was closely associated with European colonialism. Many species were planted on farms and they were also widely planted in forestry trials. For example, Poynton's [26] 882 page Tree Planting in Southern Africa Volume 2 The Eucalypts describes trials of 88 species at 271 sites. Eucalypts were widely planted not only for timber production, but also to provide fuel for steam trains, so there were many small plantings. There is a weak, but significant correlation between the number of plantations of 57 eucalypt species plantations in southern Africa included in Poynton [26] and the numbers of records of spontaneous occurrence outside plantations [27]. In other words, the more commonly cultivated a species is, the more likely it is to become invasive. E. camaldulensis is a particularly serious problem in southern Africa as it has spread down watercourses as it does naturally in Australia, establishing on silt banks after flooding and being able to survive subsequent floods (C. Harwood, pers. comm.). In contrast, E. nitens that grows well in South Africa and is widely used in plantations is not a problem as an invasive species. Interestingly, it is grown under conditions that are somewhat warmer than those within its natural distribution and does not flower, so it does not produce seed (T. Swain, pers. comm.).

Even where eucalypts are a known problem as weeds, such as E. globulus in California, it is debatable as to whether they can be considered a severe problem as invasives. For example, CAB International [28] commented "though E. globulus does not produce root suckers and does not naturally reproduce vegetatively, it still may have the potential to become a weed when seed escapes from plantations or amenity plantings. This has occurred in California, particularly around Los Angeles and San Francisco. The seed is not easily dispersed over large distances and the spread is likely to be relatively slow and hence should be easy to contain." For example, a US National Park Service [29] booklet on Eucalyptus-A transcontinental legacy describes the expansion of a grove of eucalypts on Angel Island in San Francisco Bay. This grew from an original 0.24 ha woodlot in 1915 to 0.89 ha in 1988, expanding on average by only about $0.3 \mathrm{~m}$ per year. As expansions of isolated trees in the worst direction were only about one meter per year, this could hardly be considered rapid expansion. Though the US National Park Service do consider E. globulus to be 
"invasive" in California, the US Department of Agriculture do not. Eucalypt seed generally requires bare soil in order to germinate, and the species is therefore not considered to be an aggressive colonizer. The California Invasive Plant Inventory [30] concluded that "effects are not lasting in the sense that tree removal can ameliorate impacts on ecological processes, effects are generally restricted to within stands."

\section{Regions Climatically Similar to Lower Coastal Plain}

In order to be a successful plantation species or an invasive species, any tree species must be able to grow in the target area. Beginning more than 25 years ago, methods of climatic analysis were developed in Australia to assist the conservation and use of Australian species in Australia as well as their introduction overseas (see, e.g., $[31,32]$ ). Part of this work involved the development of a global climatic mapping program [33], and this has been used to identify locations with similar climatic conditions to the Lower Coastal Plain. The climatic environment of the Lower Coastal Plain was determined in terms of ranges of six simple climatic factors that have proved useful for selecting trees worth evaluating in particular regions. The description was as follows: mean annual rainfall $1200-1650 \mathrm{~mm}$, rainfall seasonality: uniform or summer, dry season length $0-1$ months, mean maximum temperature of the hottest month $32-36^{\circ} \mathrm{C}$, mean minimum temperature of the coldest month $0-8^{\circ} \mathrm{C}$, and mean annual temperature $17-20^{\circ} \mathrm{C}$. The regions that satisfy these requirements are shown in Figure 1. Climatically similar regions outside the US include a small region in Argentina around $31.33^{\circ} \mathrm{S}$ and $58.00^{\circ} \mathrm{W}$ and a much larger region in China. The climatically similar region in China is within the general region bounded by $29.33^{\circ} \mathrm{N} 112.00^{\circ} \mathrm{E}, 29.33^{\circ} \mathrm{N} 116.67^{\circ} \mathrm{E}$, $26.00^{\circ} \mathrm{N} 111.33^{\circ} \mathrm{E}$, and $25.33^{\circ} \mathrm{N} 115.33^{\circ} \mathrm{E}$, with a couple of outliers at $28.00^{\circ} \mathrm{N} 118.67^{\circ} \mathrm{E}$ and $26.00^{\circ} \mathrm{N} 119.33^{\circ} \mathrm{E}$.

A Google search on "Argentina eucalypt* invasive*" provided a few comments that E. camaldulensis, one of the species that has been suggested as worth considering for the Lower Coastal Plain by Gonzalez et al. [1], has been reported to be an invasive species in Argentina. However, the same search on the ISI scientific database provided only five references, which all refer to invasive pests of eucalypt plantations rather than eucalypts as invasive species. At around 330000 ha the area of eucalypt plantations in Argentina is relatively modest, so it is probablymore interesting to consider the much larger climatically similar area in China.

China is the world's third largest grower of eucalypts [23] and more than 200 eucalypt species were assessed there, but only ten species are now widely grown $[34,35]$. As eucalypts were introduced into temperate regions of the northern hemisphere, it became obvious that in several locations, such as southern parts of the USA, the then USSR, and China, they could grow well for several years, but would then be very severely damaged or completely killed by sudden frost events. Some eucalypts grow in quite cold conditions in Australia, indeed some are known as "snow gums" (e.g., E. pauciflora). However, Australia is surrounded by ocean

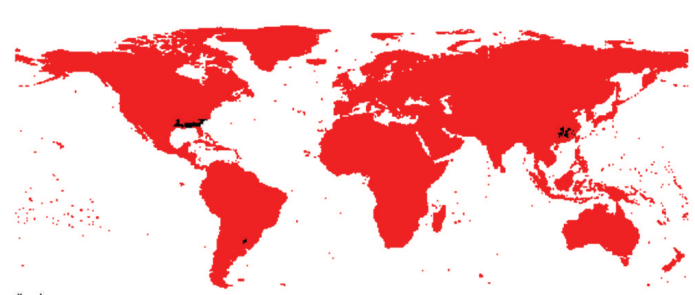

FIgURE 1: Climatically similar areas to the Lower Coastal Plain are shown in black.

to the south, so cold winds blowing from the south are moderated by the relative warmth of the ocean. Eucalypts have the opportunity to "harden" (i.e., increase their frost resistance) as temperatures gradually fall in the autumn. In contrast, temperate regions of the USA, USSR, and China have large land masses to their north. Every few years winds from the north cause temperatures to drop very rapidly and severely damage or kill eucalypts.

As part of Australia's aid program, a Chinese scientist studied for his Ph.D. in Australia on the topic "Frost prediction for Australian tree species in China" [36]. The approach he used is relevant to the selection of eucalypts for the Lower Coastal Plain as well as any consideration of where eucalypts may become invasive in frost-prone regions. Part of the study involved time series analyses for southern China for spring, winter, and autumn periods based on a dataset for the 1977-97 period. The spatial distribution of frost was described in terms of the statistical probability of different frost intensities. This provides a useful overview of frost risk across the whole region.

However, the impact of frost on eucalypts is a dynamic process, and a tree hardiness model was developed for two important Australian species, E. grandis and Acacia mearnsii. This was based on the frost hardening model that King and Ball [37] developed for E. pauciflora. The model was validated using data for E. pauciflora growing at Toulouse, France using data described by B. M. Potts and W. C. Potts [38]. Figure 2 shows how the model simulates plant hardening, that is, developing the ability to withstand frost damage as temperatures fall. If the actual daily minimum temperature falls below the simulated hardening line as it does in Figure 2, then frost damage is expected for that particular species at that particular location given the conditions for that particular year. Yan [36] ran the model for 10 locations across southern China to show how E. grandis and A. mearnsii might be subject to different levels of frost risk in different locations. With the introduction of genetically modified eucalypts and progress with identifying more frostresistant taxa the detailed results of this risk analysis are no longer relevant, but the approach of using interpolation surfaces and dynamically modelling frost resistance could well be applied in the Lower Coastal Plain to help understand both plantation potential and invasiveness risks.

Again a search was made on Google and ISI this time using the key terms "China eucalypt* and invasive*". The Google search did not produce any useful detailed reports. Most of the ten references to papers in the ISI scientific 


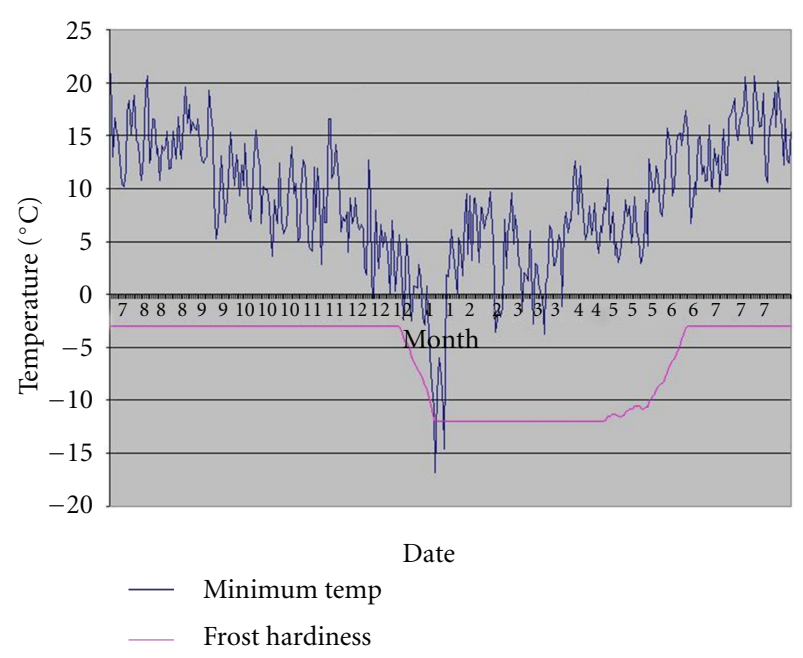

FIgURE 2: Simulation of frost hardiness and injury for E. pauciflora at Toulouse, France. The frost hardiness line shows how frost tolerance develops as daily minimum temperatures fall in winter and is lost as they rise in spring. Frost damage is expected if the minimum temperature falls below the frost hardiness line (Figure from [36]).

database were again to invasive species affecting eucalypt plantations rather than eucalypts as invasive species. However, there was one paper that considered allelopathic mediated invasions of eucalypt species in general as well as 13 other species. Another looked at how successfully three plant species, including Eucalyptus urophylla, Acacia auriculiformis, and a native species Schima superba, established themselves in plots where aboveground and belowground competition had been removed [39]. However, the experiment was somewhat artificial as the "invading" plants were planted in the plots as seedlings. The lack of information about eucalypts as invasive species in China in both the general and scientific literature suggests they are not a serious problem there.

Risk assessment for the Lower Coastal Plain should take into account changing conditions. Climate change is already reducing the severity of frosts and analyses should take into account trends in minimum temperatures [40]. However, it should not be simply assumed that climate change and milder minimum temperatures will necessarily reduce frost risks in a simple manner. Climate change is being driven by atmospheric changes, particularly rising levels of atmospheric carbon dioxide. Barker et al. [41] reported a surprising result that E. pauciflora (snow gum) seedlings when raised in open topped chambers at $2 \mathrm{x}$ ambient $\mathrm{CO}_{2}$ suffered ten-times as much frost damage as those grown in similar chambers under ambient conditions. So, some similar experiments may be required on taxa that may be used in the Lower Coastal Plain.

\section{Discussion}

The adaptations of eucalypts, which allow many species to grow successfully under often difficult conditions of poor soils and highly variable rainfall, have provided some of the characteristics that make a small number of eucalypt species particularly successful in plantations. However, the adaptations of eucalypts to fire, particularly the use of protective seed capsules has made them relatively poor as invasive species. The dispersal of seed over comparatively short distances, the small size of seed, and its limited viability under natural conditions make eucalypts not very effective as invasive species [42].

Some eucalypt species are a particular problem in southern Africa. Their early introduction and wide use outside of major plantations may have been factors in them becoming more of a problem in southern Africa than elsewhere. They appear to be less of a problem in China, possibly due to its high population density and intensive land use, so that the few unwanted seedlings that do successfully establish are quickly removed. In the United States, E. globulus is certainly a weed problem in California, but it was widely planted there in the past. The poor dispersal capabilities of the species suggest it is a problem that can be contained.

The Southern Coastal Plain is climatically most similar to regions in Argentina and China. Occasional sudden frosts are a limitation for eucalypts to grow in these regions, but interpolated climatic data can help to assess the spatial nature of these risks, while dynamic models can be used for selected locations to assess the temporal risks. One of the species being considered for planting in the Southern Coastal Plain, E. camaldulensis, is reported to be an invasive species in Argentina, but there appears to be little evidence that invasive eucalypt species are a problem in China.

Both the general experience of eucalypts around the world and the experience from regions similar to the Lower Coastal Plain suggest that the establishment of eucalypt plantations in the region should not create a great problem with eucalypts being invasive. This is not to say there is no risk. One obvious way to reduce the risk dramatically would be to plant taxa that do not produce seed. Though it is not always the case, there is a tendency for short rotation (i.e., sixseven year) clonal stands of eucalypts, such as those in Brazil, to seldom produce flowers (A, Almeida, pers. comm.). Part of the ArborGen trials [22] are concerned with producing sterile genotypes, so that any genetically modified eucalypts that entered general use would not be capable of producing viable seed.

\section{Conclusions}

Assessing whether particular taxa can grow in particular regions is as important for assessing invasiveness risks as it is for selecting suitable taxa for commercial production. It would be useful to carry out similar climatic analyses for the Lower Coastal Plain to those already carried out for southern China [36]. The development of both interpolated frost risk data (probably at a $1 \mathrm{~km}$ or finer resolution) and running frost risk simulation models for particular taxa at selected locations (possibly for a coarser grid) would help to select suitable taxa for planting and assess the risks associated with occasionally severe frosts. Loehle et al. [3] provide an example of interpolated minimum temperature data for the Lower Coastal Plain. 
Eucalypts have been used in the United States for many years [43], but biofuel production provides new opportunities. Experience from around the world suggests that eucalypts are unlikely to cause a major problem as invasive species in the Lower Coastal Plain. Simple management practices, such as avoiding planting trees near watercourses and maintaining clear firebreaks, will reduce the chances of eucalypts spontaneously occurring outside plantations. Any potential risk could be greatly reduced by planting sterile genotypes, whether genetically modified organisms or clones. Even if nonsterile trees are grown the use of short rotations should reduce the chance of any trees flowering and producing seed. But whatever genotypes are grown (whether GMOs, clones, or otherwise) new plantations should be carefully monitored to check on seed production and to ensure that the trees are not invasive.

\section{Acknowledgments}

The author is grateful to the National Council for Air and Stream Improvement, Inc. (NCASI) and the USDA Forest Service Southern Research Station for their support which allowed him to attend the "Symposium on the Assessment and management of Environmental Issues related to Eucalyptus Culture in the Southern United States," held in Charleston, South Carolina, February, 22-24 2012. This paper is based on his presentation at that symposium. The author thanks also his former Ph.D. student, now Dr. Yan Hong, for the permission to include Figure 2. Insightful review comments were provided by CSIRO reviewers, Chris Harwood, and David Bush as well as three anonymous reviewers.

\section{References}

[1] R. Gonzalez, T. Treasure, J. Wright et al., "Exploring the potential of Eucalyptus for energy production in the Southern United States: financial analysis of delivered biomass. Part I," Biomass and Bioenergy, vol. 35, no. 2, pp. 755-766, 2011.

[2] J. L. Stape, "Recent developments in Eucalyptus culture," International Journal of Forestry Research. In press.

[3] C. Loehle, D. Rockwood, and J. Beebe, "Potential invasiveness of nine Eucalyptus species in the Southeastern United States: a summary of the literature," International Journal of Forestry Research. In press.

[4] D. Simberloff and M. Rejmánek, Eds., Encyclopedia of Biological Invasions, University of California, Berkeley, Calif, USA, 2011.

[5] J. Wrigley and M. Fagg, Eucalypts-A Celebration, Allen \& Unwin, Crows Nest, Australia, 2010.

[6] M. E. White, The Greening of Gondwana, Reed, Frenchs Forest, Australia, 1986.

[7] G. M. Chippendale, Eucalyptus, Angophora (Myrtaceae), Flora of Australia, Commonwealth of Australia, Canberra, Australia, 1988.

[8] T. H. Booth, Ed., "Climate Change and the 2009 Bushfires," CSIRO Submission 09/345 prepared for the 2009 Victorian Bushfires Royal Commission, 2009, http://www.royalcommission.vic.gov.au/Submissions.

[9] A. G. Brown, J. W. Turnbull, and T. H. Booth, "The Australian environment," in Australian Trees and Shrubs: Species for Land Rehabilitation and Farm Planting in the Tropics, D. C. Doran and J. W. Turnbull, Eds., ACIAR Monograph no. 24, Australian Centre for International Agricultural Research, Canberra, Australia, 1997.

[10] J. Williams and J. C. Z. Woinarski, Eds., Eucalypt Ecology: Individuals to Ecosystems, Cambridge University, 1997.

[11] K. W. Cremer, "Distance of seed dispersal in eucalypts estimated from seed weights," Australian Forest Research, vol. 7, no. 4, pp. 225-228, 1997.

[12] I. Abbott and O. Loneragan, Ecology of Jarrah (Eucalyptus marginata) in the Northern Jarrah forest of Western Australia, Bulletin No. 1, Department of Conservation and Lanad Management, Perth, Australia, 1986.

[13] A. B. Wellington and I. R. Noble, "Seed dynamics and factors limiting recruitment of the mallee Eucalyptus incrassata, in semi-arid, south-eastern Australia," Journal of Ecology, vol. 73, no. 2, pp. 657-666, 1985.

[14] R. J. Grose, "Effective seed supply for the natural regeneration of Eucalyptus delegatensis R.T. Baker, syn. Eucalyptus gigantean Hook. F.", Journal of the Australian Pulp and Paper Industry Association, vol. 13, no. 4, pp. 131-147, 1960.

[15] K. X. Ruthrof, W. A. Loneragan, and C. J. Yates, "Comparative population dynamics of Eucalyptus cladocalyx in its native habitat and as an invasive species in an urban bushland in south-western Australia," Diversity and Distributions, vol. 9, no. 6, pp. 469-483, 2003.

[16] L. D. Pryor, The Biology of Eucalypts, Edward Arnold, Southampton, UK, 1976.

[17] N. C. W. Beadle, "Some aspects of ecology and physiology of Australian xeromorphic plants," Australian Journal of Science, vol. 30, no. 9, pp. 348-355, 1968.

[18] M. R. Jacobs, Eucalypts for Planting, FAO, Rome, Italy, 2nd edition, 1981.

[19] K. Eldridge, J. Davidson, C. Harwood, and G. van Wyk, Eucalypt Domestication and Breeding, Cambridge University, 1994.

[20] C. Harwood, "Introductions: doing it right," in Developing a Eucalypt Resource: Learning from Australia and Elsewhere, J. Walker, Ed., pp. 43-54, Wood Technology Research Centre, University of Canterbury, Christchurch, New Zealand, 2011.

[21] A. G. Bassa, M. Hinchee, W. Rottman, B. Kwan, and M. Cunningham, "Transgenic technologies of Eucalyptus," in Proceedings of the IUFRO Conference on Improvement and Culture of Eucalypts, J. L. M. Goncalves, Ed., p. 82, ESALQ, Piracicaba, Brazil, 2011.

[22] USDA/APHIS, Environmental Assessment on 'Field testing of genetically engineered Eucalyptus grandis X Eucalyptus urophylla, United States Department of Agriculture, Animal and Plant Health Inspection Service, Biotechnology Regulatory Services, Washington, 2010, http://www.aphis.usda.gov/brs/ aphisdocs/08_014101r_ea.pdf.

[23] GIT Consulting, Eucalyptus Universalis-Cultivated Eucalypt Forests Global Map, 2010, http://git-forestry.com/download_ git_eucalyptus_map.htm.

[24] K. A. Haysom and S. T. Murphy, "The status of invasiveness of forest tree species outside their natural habitat: a global review and discussion paper," Forest Health and Biosecurity Working Paper FBS/3E, FAO, Rome, Italy, 2003.

[25] D. M. Richardson and M. Rejmánek, "Trees and shrubs as invasive alien species-a global review," Diversity and Distributions, vol. 17, no. 5, pp. 788-809, 2011.

[26] R. J. Poynton, Tree Planting in Southern Africa Volume 2 The Eucalypts, Department of Forestry, Pretoria, South Africa, 1979. 
[27] M. Rejmánek, "Invasive plants: Approaches and predictions," Austral Ecology, vol. 25, no. 5, pp. 497-506, 2000.

[28] CAB International, Forestry Compendium CDROM, CABI, Wallingford, UK, 2005.

[29] US National Park Service, Eucalyptus-A Transcontinental Legacy, Golden Gate NRA, San Francisco, Calif, USA, 2006, http://biomass.forestguild.org/casestudies/1001/Eucalyptus .pdf.

[30] California Invasive Plant Council, "California Invasive Plant Inventory," Cal-IPC Publication 2006-2, California Invasive Plant Council, Berkeley, Calif, USA, 2006.

[31] T. H. Booth, "A new method for assisting species selection.," Commonwealth Forestry Review, vol. 64, no. 3, pp. 241-250, 1985.

[32] T. H. Booth, Matching Trees and Sites. Proceedings of an International Workshop Held in Bangkok, 27-30 March 1995, ACIAR Proceedings No. 63, ACIAR, Canberra, Australia, 1996.

[33] T. H. Booth, T. Jovanovic, and M. New, "A new world climatic mapping program to assist species selection," Forest Ecology and Management, vol. 163, no. 1-3, pp. 111-117, 2002.

[34] D. W. McKenney, J. S. Davis, J. W. Turnbull, and S. D. Searle, "Impact of Australian tree species selection research in China: an economic perspective," Forest Ecology and Management, vol. 60, no. 1-2, pp. 59-76, 1993.

[35] J. W. Turnbull, "Eucalypt plantations," New Forests, vol. 17, no. 1-3, pp. 37-52, 1999.

[36] H. Yan, Frost prediction for Australian tree species in China [Ph.D. thesis], Australian National University, Canberra, Australia, 2001.

[37] D. A. King and M. C. Ball, "A model of frost impacts on seasonal photosynthesis of Eucalyptus pauciflora," Australian Journal of Plant Physiology, vol. 25, no. 1, pp. 27-37, 1998.

[38] B. M. Potts and W. C. Potts, "Eucalypt breeding in France," Australian Forestry, vol. 49, no. 4, pp. 210-218, 1986.

[39] X. YanCi, P. ShaoLin, P. XiuHua, and R. XingQuan, "Measures of plant competition among three species of transplanted tree seedlings," Acta Phytoecologica Sinica, vol. 29, no. 5, pp. 724729, 2005.

[40] T. H. Booth, M. U. F. Kirschbaum, and M. Battaglia, "Forestry," in Adapting Agriculture to Climate Change, C. Stokes and M. Howden, Eds., pp. 137-152, CSIRO, Melbourne, Australia, 2010.

[41] D. H. Barker, B. R. Loveys, J. J. G. Egerton, H. Gorton, W. E. Williams, and M. C. Ball, " $\mathrm{CO}_{2}$ enrichment predisposes foliage of a eucalypt to freezing injury and reduces spring growth," Plant, Cell and Environment, vol. 28, no. 12, pp. 1506-1515, 2005.

[42] M. Rejmánek and D. M. Richardson, "Eucalypts," in Encyclopedia of Biological Invasions, D. Simberloff and M. Rejmánek, Eds., pp. 203-209, University of California, Berkeley, Calif, USA, 2011.

[43] A. J. McClatchie, Eucalypts Cultivated in the United States, Bulletin no. 35, U.S. Department of Agriculture, Bureau of Forestry, 1902. 

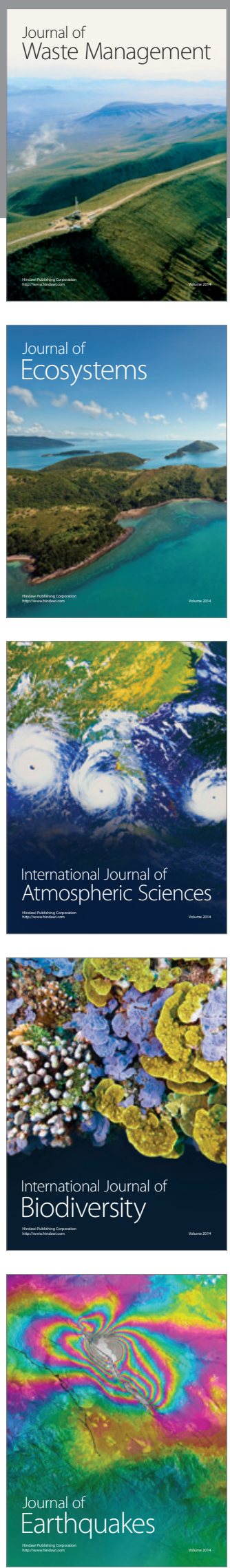
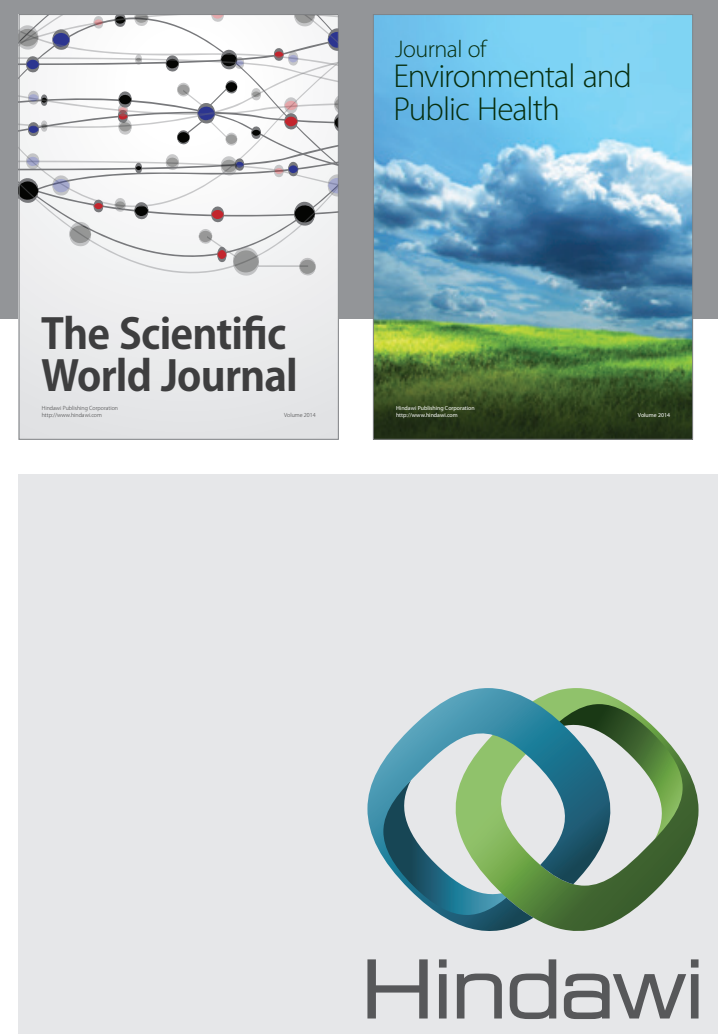

Submit your manuscripts at

http://www.hindawi.com
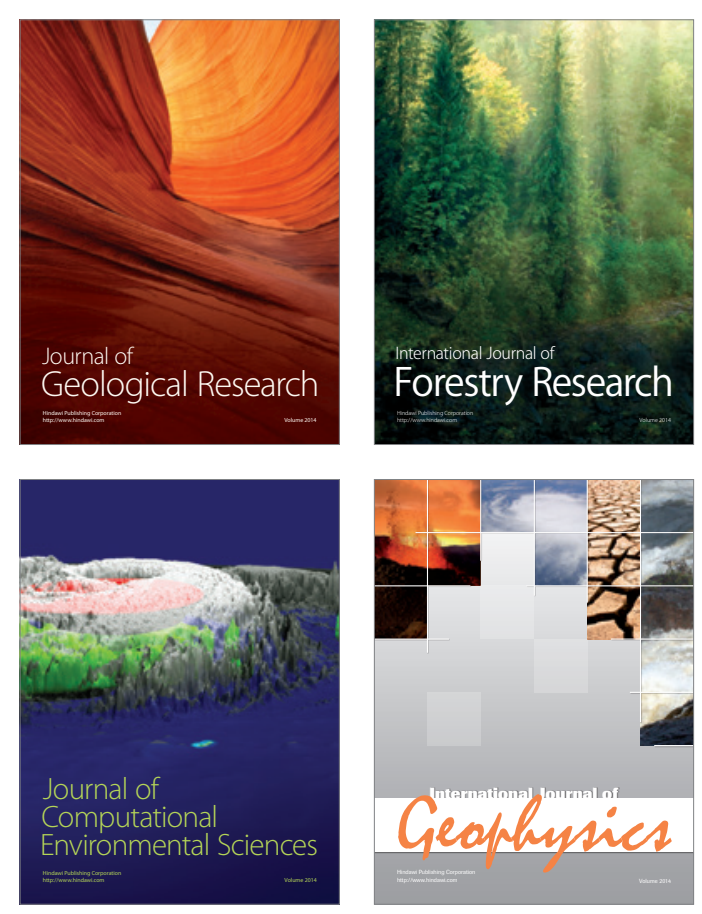
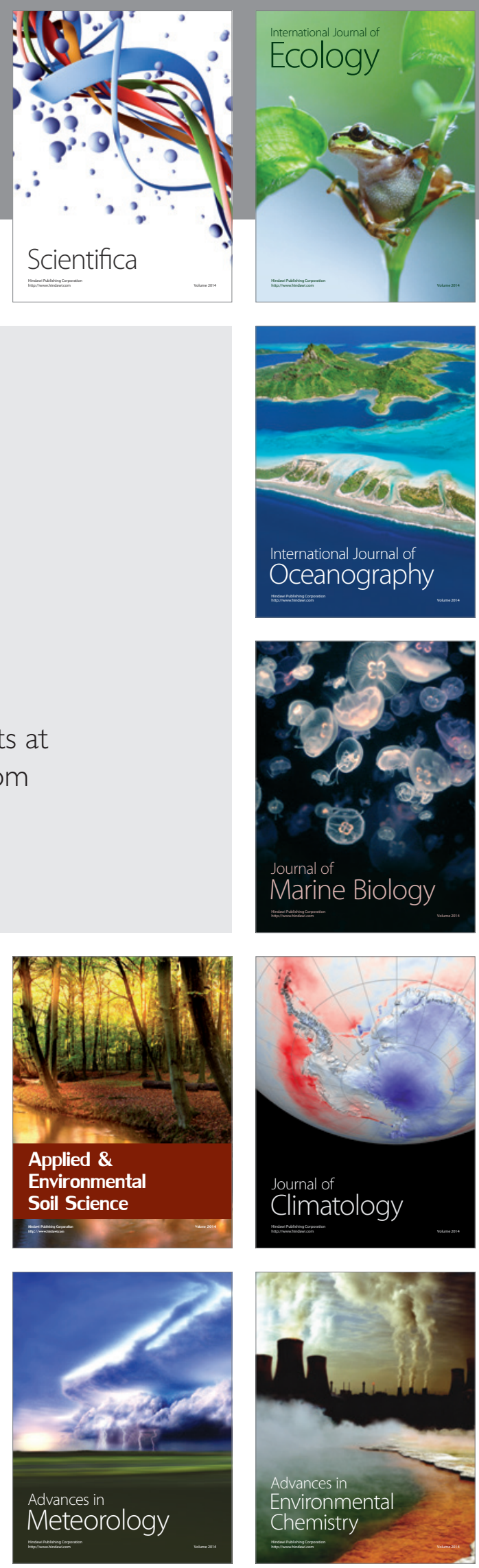